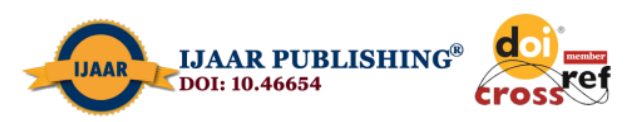

International Journal of Advanced Academic Research (Sciences, Technology and Engineering) | ISSN: 2488-9849

Vol. 6, Issue 12 (December, 2020) |www.ijaar.org

Journal DOI: 10.46654/ij.24889849

Article DOI: 10.46654/ij.24889849.e61233

\title{
ENVIRONMENTAL AND HEALTH EFFECTS OF CLIMATE CHANGE IN KADUNA METROPOLIS
}

\author{
Simon Stephen Mshelia ${ }^{1}$, Ogar Paschal Unimke ${ }^{2}$, Andrew Reigns ${ }^{2}$ and \\ Oyetunji Adewale Bashir ${ }^{2}$ \\ 1. Department of Geography, Federal University Gashua, Yobe State \\ 2. Department of Geography, Nigerian Defence Academy, Kaduna \\ Email: msheliasimon48@ gmail.com \\ Tel: +2348035755461
}

\begin{abstract}
This study examined environmental and health effects of climate change in Kaduna metropolis. Primary data were obtained through randomly administered 184 structured and semi structured survey questionnaires to purposefully selected groups of people, workers and students in the metropolis. Secondary data were obtained from desk reviews of other literatures and interviews of staff of Nigerian Metrological (NiMET) Agency and Ministry of Environment Kaduna. Descriptive statistics using Likert rating scale was employed for the analyses of the data. Findings revealed percentage range of strongly agree and agree of $80 \%-59.8 \%$ that climate change has negative environmental and health effects in Kaduna metropolis. The environmental effects identified are: flooding, desert encroachment, drought, land degradation, run-off, soil erosion, loss of water resources and biodiversity and poor agricultural productions while the health effects are: hyperthermia, vector and water borne diseases (cholera, malaria), heart ailments, dehydration and diseased crops. The study also discovered that the comprehension of the concept climate change in the metropolis is limited. Finally, the study recommends intensive public education and enlightenment on the causes and effects of climate change, strong legislations and enforcement of environmental laws and adaptation measures.
\end{abstract}

Keywords: Climate Change, Biodiversity, Drought, Hyperthermia and Effect 


\section{INTRODUCTION}

The environment which has suffered neglect in the past fifty years has today become a subject of concern not only to the underdeveloped world but also to the developed economies as a result of divers environmental problems the world at large is presently facing (especially in the under developed countries) which Nigeria counts as one. The $21^{\text {st }}$ century, arguably has been witnessing unprecedented growth in the fields of science and technology, population growth and upsurge of urban centres. The multifarious anthropogenic activities of man as well as natural forces have contributed immensely to the divers environmental and health problems facing the world where the most hit are the under developed countries such as Nigeria (Butu and Mshelia, 2017; Audrey, 2019). One significant environmental problem among many which has captured the attention of the world (scientists and politicians) over the years because of its severe effects is the climate change. The emergence of this unique phenomenon through its indicators had led to many conventions and seminars in order to mitigate the impacts and adaptive measures.

The climate of the different belts or zones in Nigeria has been experiencing changes over time as a result of natural processes also referred to as bio-geographical and anthropogenic that is the human activities through increase in temperature; changeable or fluctuating rainfall and increase in sea level and flooding. Other indicators of climate change are drought and desert encroachment; debasement of land (degradation); extreme weather conditions; shrinking water resources (lakes) and loss of biodiversity (Elisha et al., 2017; Ebele and Emodi, 2016; Olaniyi et al., 2013). While precipitation has continued to increase and the sea level equally aggravates flooding and drench of the coastal lands (Elisha et al., 2017; Akande et al., 2017; Ebele and Emodi, 2016) rise in temperature and short falls in precipitation continues to surmount and predominates in the north (Elisha et al., 2017; Amanchukwu et al., 2015; Olapido, 2010). This further indicates the fact that climate change is a national phenomenon but the various challenges linked to it differs across the country as perhaps across regions (Federal Ministry of Environment, 2014). Previous studies indicate two-thirds of some northern states such as Borno, Yobe, Gombe, Bauchi in the Northeast; Katsina, Zamfara, Kaduna, Sokoto and Kebbi in Northwest could be under desert encroachment in the $21^{\text {st }}$ century (Sayne, 2011).

It is evident that the insatiable quest for urbanization in Kaduna metropolis with little consideration to the environmental and health effects of climate change has led to the numerous anthropogenic activities by the government under the Kaduna Master Plan and Urban Development, corporate organizations and individuals. The on-going massive urban development where much green vegetation have been indiscriminately destroyed to give way to roads and other infrastructural development further exposes the city to climate change (Mshelia, et al. 2020). Mande (2020) reported that the trend of rainfall and temperature in Kaduna metropolis over a decade continues to go upward at $408 \mathrm{~mm}$ and $0.1996^{\circ} \mathrm{C}$ respectively while the average evaporation falls at $163 \mathrm{~cm} \mathrm{yr}-1( \pm 9 \%)$ and relative humidity was discovered to rise to $66.5 \%$. The changeable natures of the rainfall regime and its seasonal fluctuations have been significantly contributing to flooding in the metropolis as well intense temperature conditions. These are vivid indicators of climate change. It is on these bases that this study examined the environmental and health effects of climate change in Kaduna metropolis. 


\section{CONCEPTUAL CLARIFICATIONS}

The study attempted the definitions, explanations and indicators of climate change. Factors responsible for the climate change and the effects were also discussed.

\section{Concepts of Climate Change}

According to Intergovernmental Panel on Climate Change (IPCC) 4th Assessment Report (2007) that by the year 2020 (this year) between 75 and 250 million people living in Africa may be liable to increased water stress as a result of climate change. This has already affected livelihoods in the region negatively and would continue to as long as the climate change is experienced. IPCC further reported that owing to the climate change in the areas, there is the tendency that the time frames and the length of the season for the cultivation of certain crops at notable good fields may decrease. Similarly, yields from rain-fed agriculture in some countries could be reduced to about 50\%. Thus, climate change may have particularly serious consequences in the developing world, where some 800 million people are malnourished and living in abject poverty. The World Bank (2008) further emphasized that $75 \%$ of the world's poor live in rural areas in developing countries and most relied on agricultural activities for their means of livelihoods.

Nenibarini (2007) opined that climate refers to the average weather of the interacting components of the environment over long period of time (about 35 years) of a region and this includes typical weather patterns, the frequency and intensity of storms, cold spells and hot weather. Nenibarini (2007) further postulates climate change as the kind of change in climate that is directly or indirectly ascribed to activities of human beings that affect the environment and pave ways to global warming. De Chavez and Tauli-Corpus (2008) opined that the term climate is the assertion of a highly complex system consisting of five inter-relating components of the environment namely: the atmosphere (air), the hydrosphere (water), cryosphere (frozen part of the earth), the lithosphere (land surface) and the biosphere (section of the earth that has life). Climate change has the capacity to greatly affect all natural systems and this becomes a threat to human survival and development socially, politically and economically.

Furthermore, United Nations Framework Convention on Climate Change (UNFCCC, 1992) defines climate change as a transmute of climate which is ascribed directly or indirectly to activity of human that modifies the components of the atmosphere as well as natural climate variability which was observed over comparable periods of time usually one or more decades. It suffices to say that the most pivotal points that describe the concept of climate change is the time involved, the level of variability that the change is enthralled to, the duration and impact of such variability on human and the ecosystem (Elisha et al., 2017).

\section{Factors Responsible for Climate Change}

The day to day activities of man and other natural forces operating within the atmosphere contributed immensely to climate change. For instance, chlorofluorocarbon (CFC) releases or escapes either from air conditioner or fridge in small quantity to the atmosphere affects the ozone layer. Similarly, urban centres are characterized by high population, industrial activities and high volume of vehicular flows among others which exert pressures on land and atmospheric resources. These activities have strong greenhouse effects in which gases such as that methane 
gas $\left(\mathrm{CH}_{4}\right)$, carbon dioxide $\left(\mathrm{CO}_{2}\right)$ and nitrous oxide $\left(\mathrm{N}_{2} \mathrm{O}\right)$, sulphur hexafluoride enter into the atmosphere and contribute to climate change (Houghton, 2011). It was on the basis of this submission of the anthropogenic factors that Vitousek et al. (1997) stated that "Human alteration of Earth is substantial and growing. Between one-third and one-half of the land surface has been transformed by human action; the carbon dioxide concentration in the atmosphere has increased by nearly $30 \%$ since the beginning of the Industrial Revolution; more atmospheric nitrogen is fixed by humanity than by all natural terrestrial sources combined; more than half of all accessible surface fresh water is put to use by humanity; and about one-quarter of the bird species on Earth have been driven to extinction. By these and other standards, it is clear that we live on a human-dominated planet."

The UNFCCC further makes a contrast between climate changes linkable to anthropogenic activities changing or recasting the composition of the atmosphere and the environment in general and climate variability which can be ascribed to natural causes. Buba (2004)and Odjugo (2007) reported that for the past few decades, anthropogenic factors such as transportation, industrialization, urbanization, burning of fossil fuel, agriculture, water pollution, changes in land cover and deforestation among others are the major contributing factors to the depletion of the ozone layer and its associated global warming and climate change. Based on the anthropogenic activities, it is not out of place to say man is at the nucleus of climate change through activities that increase the amount of greenhouse gases in the atmosphere (Akpodiogaga and Odjugo, 2010).

\section{Effects of Climate Change}

The effects of climate change are enormous and directly or indirectly have bearing on the environment and health of human, animals and plants among others. Jeffe (2012) also reported that climate change had different negative environmental and health effects. The environmental effects are: extreme events (such as rise in temperature, lightning and thunderstorm among others), rise in sea level, flooding, desert encroachment, drought, land degradation, run-off, soil erosion and food scarcity while the health impacts are: increase of heat which leads dehydration and spread of diseases such as; hyperthermia, skin cancer, cholera, malaria, malnutrition, heart ailments, damage of public health infrastructure, and migration of man (Orisa-Ubi. 2020). It on this basis of the health effects of climate change that Hippocrates (1978) stated that "whoever wishes to investigate medicine properly, should proceed thus: in the first place to consider the seasons of the year, and what effects each of them produces, for they are not all alike, but differ much from themselves in regard to their changes".

\section{MATERIALS AND METHODS Study Area}

Kaduna metropolis which consists of the Kaduna North and South as well as some parts of Chikun and Igabi Local Government Areas of the State is located between Latitudes $10^{\circ} 20^{\prime} \mathrm{N}$ and $10^{\circ} 37^{\prime} \mathrm{N}$ of the Equator and Longitudes $7^{\circ} 22^{\prime} \mathrm{E}$ and $7^{\circ} 31^{\prime} \mathrm{E}$ of the Greenwich Meridian (Figure 1). The metropolis covers an area of about $260 \mathrm{Km}^{2}$ and the distance between the eastern and western limits of the city is approximately $13.7 \mathrm{~km}$ (Fingesi, 2001; Al-Amin and DadanGarba 2014). 


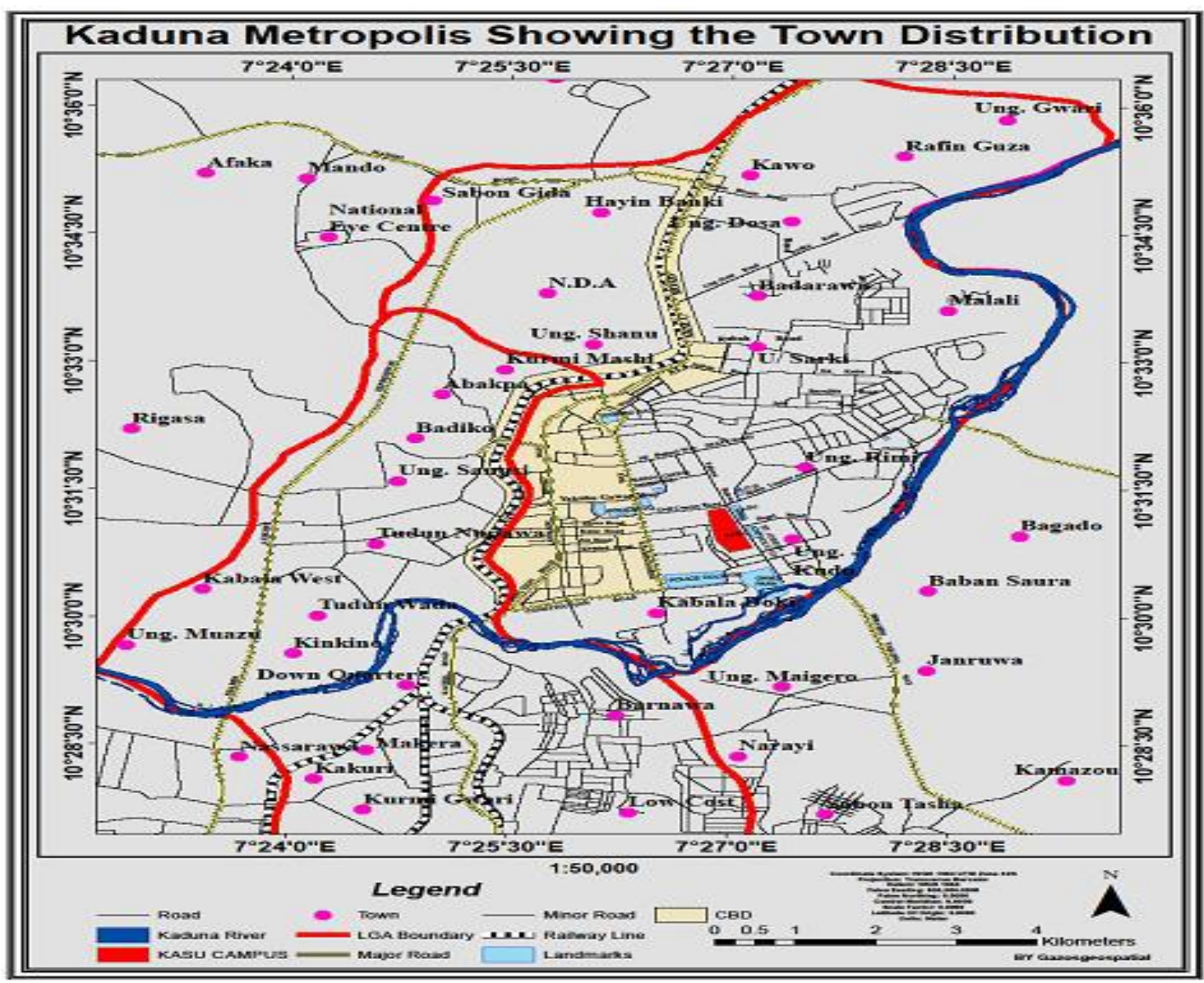

Figure 1: Map of Kaduna Metropolis

Source: Mande (2020)

The climate of the study area is tropical in nature with divergent seasonal trends and variability that swings back and forth between cool to hot dry and from humid to wet, with average annual temperature of $25.2^{\circ} \mathrm{C}$ and sometimes it reaches $29-30^{\circ} \mathrm{C}$ (Abaje et al. 2016; Benedine and Adamu, 2017). Rainfall durations fluctuates between 150days to 190days amounting an annual rainfall of between $1500 \mathrm{~mm}$ to $2000 \mathrm{~mm}$. The relative humidity falls between $20 \%$ and $30 \%$ in January and rises to between 60\% and as high as 80\% in July (Mshelia et al., 2020; Al-amin and Dadan-Garba, 2014). The climate of the areas is experiencing threat from the climate change as a result of the natural and anthropogenic factors.

Vegetation of Kaduna is basically of the Guinea savanna characterized by tall and short grasses and scattered trees of species made up of Eucalyptus spp,Azadiracta indica, Psidium guajava, Terminalia catapa, Mangifera indica, Anacardium occidentalis, Khaya senegalensis, Gmelina arboria, pinus spp, Carica papaya, Gliricidia sepium, Ficus spp, Afzelia spp, Balanite eagyptiaca, Borassus aethiopum, Persae americana, Polyantha longifolia, and (Entandrophragma cylindricum) among others (Ogunkalo et al, 2017). Some of these 
vegetations are locally known as oil and dum palms, shea butter, isoberlina, tamarind, baobab, black plum, elephant grass and guinea grass among others. The natural vegetation has been modified through man's activities such bush burning, crops cultivations, grazing (pastoral farming), constructions and urbanization. These give rooms for climate change.

\section{Methods of Data Collection and Analysis}

Primary data were generated from structured, semi structured, open survey questionnaires and field interview questions in a pre-formulated pattern; situations where follow up questions were asked to elucidate questions and responses during interviews (Mshelia et al., 2020). Staff of Nigerian Metrological (NiMET) Agency and Ministry of Environment Kaduna as well as 184 residents of the metropolis were randomly; systematically and purposefully selected, administered questionnaires and interviewed on environmental and health effects of climate change. Preference was accorded to the civil/public servants, students of Geography and Environmental studies, Kaduna State University as well as farmers and elders within the age of forty and above. The categories were specially considered because of the topic climate change requires people that have idea of what it means as previous studies by BBC World Service Trust: climate talk in (2008) reported that the knowledge of the people in Kaduna Northern Nigeria is limited. The secondary data were obtained from desk review of literatures and records from NiMET and Kaduna State Ministry of Environment on climate change in the metropolis. Other sources of data were obtained from documents or materials such as journals, textbooks, the proceedings of seminars and other research works. Descriptive statistics was employed and results obtained were presented in tables in simple arithmetic mean and frequency using Likert Rating Scale of Strongly Agree (SA), Agree (A), Neutral (N), Disagree (D) and Strongly Disagree (SD).

\section{RESULT AND DISCUSSION}

\section{Environmental Effects of Climate Change in Kaduna Metropolis}

The perceptions of 184 respondents were inquired on the environmental effects of climate change in Kaduna Metropolis under eight views as shown on Table 3.1. On the aspect of climate change/variability and extreme events lead to flooding in the metropolis especially along the river basin, respondents of $20.7 \%$ strongly agreed, the highest of $39.1 \%$ agreed, $18.5 \%$ of the respondents were neutral (sat on the wall), $14.1 \%$ disagreed while $7.6 \%$ strongly disagreed with the view. This reveals that climate change leads to flooding in the metropolis especially along the river basin. The finding is similar to the research work of Mande (2020). Similarly, 26.6\% strongly agreed that climate change gradually exposes the metropolis to drought and desert encroachment. The highest percentage of $42.4 \%$ agreed with the view, $15.2 \%$ recorded neutral and $7.1 \%$ disagreed while the least respondents of $8.7 \%$ strongly disagreed. This shows that climate change (extreme events) gradually exposes the metropolis to drought and desert encroachment as also asserted by Sayne (2011). The study in consideration of view 3 on Table 3.1 further indicates that $31.5 \%$ strongly agreed that climate change degrades and devalues land in the metropolis. The highest respondents of $44.6 \%$ agreed; neutral recorded $6.5 \%$ and $12 \%$ 
disagreed while $4.9 \%$ strongly disagreed. This reveals that climate change contributes to land degradation. Orisa-Ubi (2020) who studied health and environmental impacts of climate change in Rivers State is in agreement with the finding of this view of land degradation. Similarly, $44.6 \%$ strongly agreed that extreme events such as lightning and thunderstorm, high temperature among others destroy lives and properties such as houses or structures, $6.5 \%$ reported neutral (showed no response), $12 \%$ disagreed and $5.4 \%$ strongly disagreed. This indicates that the extreme events and climate variability contributes significantly to destruction of lives and properties as reported by Orisa-ubi (2020).

Table 3.2: Environmental Effects of Climate Change in Kaduna Metropolis

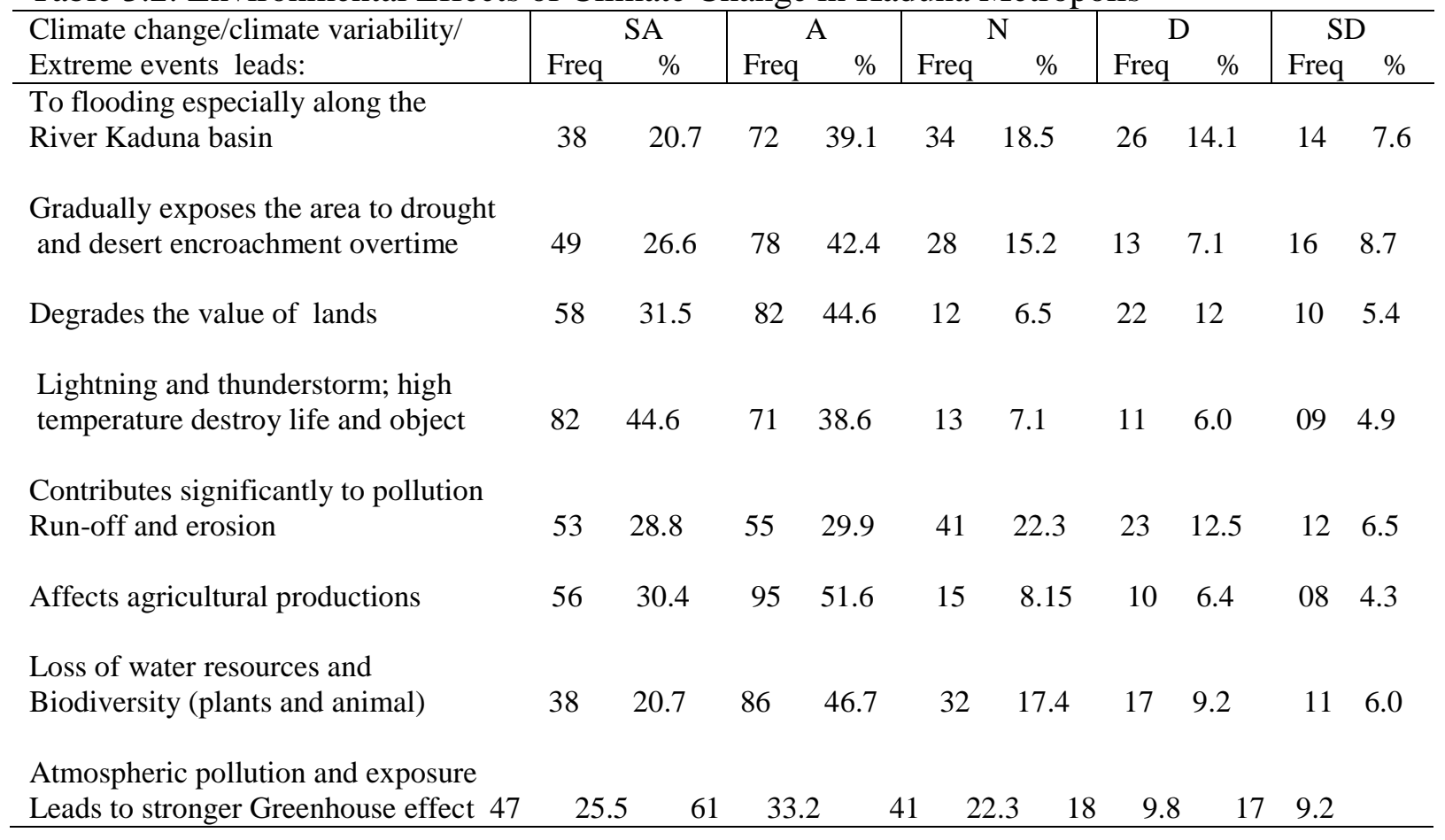

$\mathrm{SA}=$ Strongly Agree, A=Agree, $\mathrm{N}=$ Neutral, Disagree-=D, SD=Strongly Disagree, Freq = Frequency \%=Percentage Source: Field Survey, (2020)

Further investigation on the environmental effects of climate change as shown on Table 3.1 reveals that $28.8 \%$ of the respondents are strongly of the view that it contributes significantly to pollution, run-off and erosion, 29.9\% agreed, neutral (no response) recorded $22.3 \%$ and $12.5 \%$ disagreed while $6.5 \%$ strongly disagreed. This reveals that climate change contributes to pollution, run-off and erosion despite the closeness in the responses. This result is in agreement with the study carried out by Akeh and Mshelia, (2016) and Amanchukwu et al. (2015). On the aspect of the view that climate change affects agricultural production through decrease in crop yields received a response of $30.4 \%$ of those who strongly agreed. The highest response of $51.6 \%$ agreed, $8.2 \%$ showed no response while $5.4 \%$ disagreed and the least respondents of $4.3 \%$ strongly disagreed with the view. The study therefore indicates that climate change affects agricultural production. Elisha et al., (2017) reported similar result. Further quest on the environmental effects of climate change shows that $30.7 \%$ strongly agreed that climate change leads to loss of water resources and biodiversity. The highest respondents of $46.7 \%$ agreed, 
neutral recorded $17.4 \%$ and $9.2 \%$ disagreed while only $6 \%$ strongly agreed with the view. This reveals that climate change leads to losses of water resources and biodiversity which affects or weaken the ecosystem as also observed by Ebele and Emodi (2016 and Olaniyi et al. (2013). The last view on the environment effect of climate change inquired the view of the respondents that atmospheric pollution and exposure to extreme events lead to stronger Greenhouse effect where $25.5 \%$ strongly agreed, $33.2 \%$ agreed, $22.3 \%$ showed no response (neutral), $9.8 \%$ disagreed and $9.2 \%$ strongly disagreed. This shows that climate change has strong Greenhouse effect as also reported by Mshelia et al. (2020) and BBC World Service Trust (2008).

The findings can further be illustrated as in Figure 3.1. It explains the tract of the environmental effects of climate change in Kaduna metropolis and also applicable in Northern States of the country.

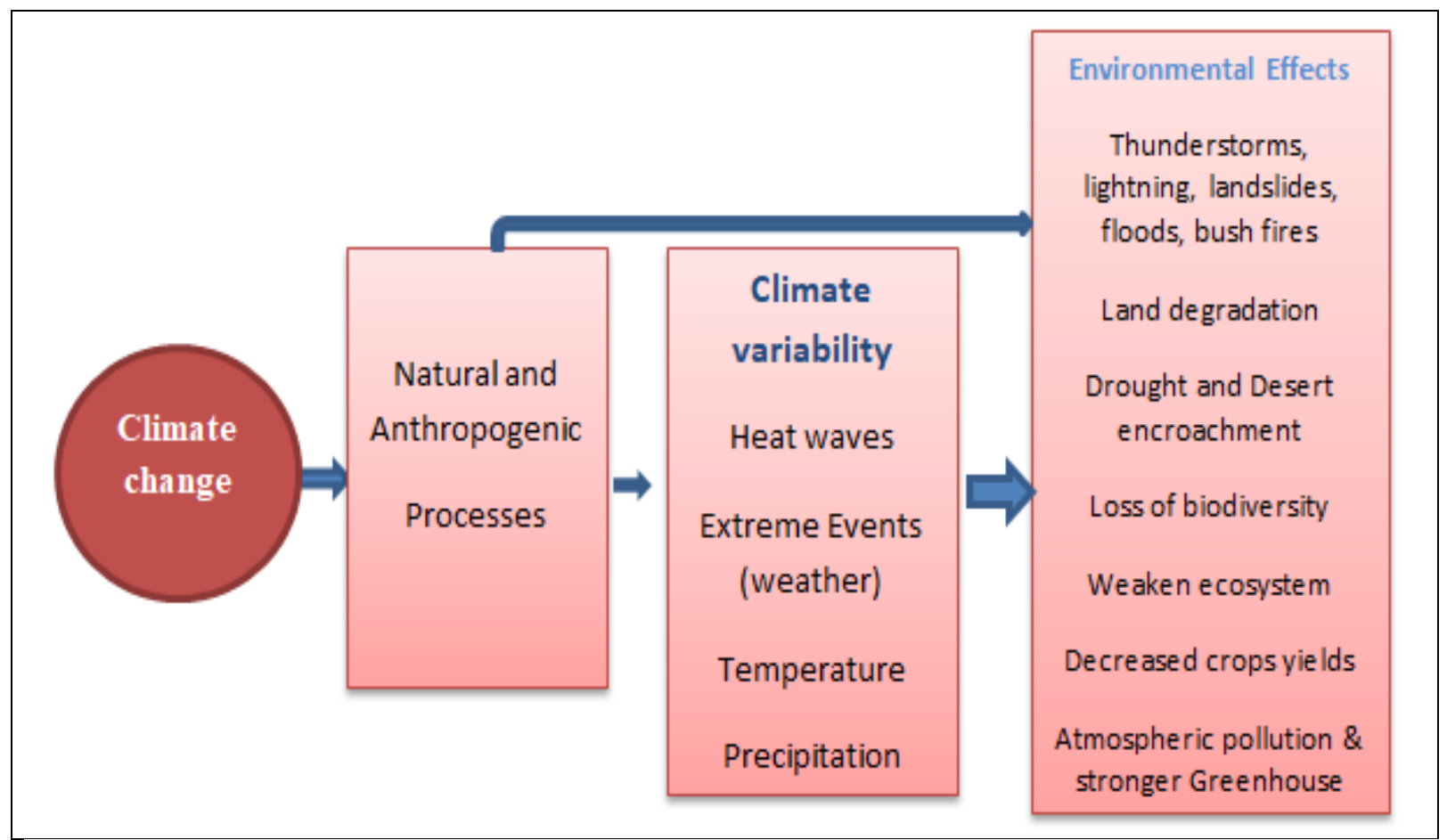

Figure 3.1: Tracts of the environmental effects of climate change

Source: Field Survey, (2020)

\section{Health Effects of Climate Change in Kaduna Metropolis}

The opinions of 184 respondents were inquired on the health effects of climate change in Kaduna Metropolis as done to environmental effects in seven perceptions. Thus: on the aspect climate change leads to water borne infectious disease such as malaria and schistosomiasis among others. Respondents of $29.3 \%$ strongly agreed, the highest of $39.2 \%$ agreed, $14.7 \%$ of the respondents were neutral, $9.8 \%$ disagreed while $6.5 \%$ strongly disagreed with the view. This reveals that climate change leads to water borne infectious diseases; a breeding place of pathogens as also reported by Orisa-Ubi (2020). On the view of hyperthermia, 28.3\% strongly agreed that climate change as a result of extreme events leads to high body temperature known as hyperthermia. The highest percentage of $37 \%$ agreed with the view, $20.1 \%$ recorded neutral and $8.2 \%$ disagreed 
while the least respondents of $6.5 \%$ strongly disagreed. This shows that extreme events can result to hyperthermia which affects the health status of living things as similarly reported by Amadi and Udo (2015). The study further indicates that $23.4 \%$ strongly agreed that climate change aids air pollution which leads to heart ailments such as respiratory diseases. The highest respondents of $42.4 \%$ disagreed; neutral recorded $13 \%$ and $14.7 \%$ disagreed while $8.7 \%$ strongly disagreed. This reveals that climate change contributes to respiratory diseases. Amanchukwu, et al. (2015) obtained similar perception. Similarly, 30.9\% strongly agreed it pave ways for increase in transmission of diseases, $42.4 \%$ disagreed, and $10.9 \%$ reported neutral (showed no response), 9.2\% disagreed and $7.1 \%$ strongly disagreed. This indicates that the extreme events and climate variability contribute significantly for the transmission of diseases in the metropolis as also reported by Orisa-ubi (2020).

Table 3.2: Health Effects of Climate Change in Kaduna Metropolis

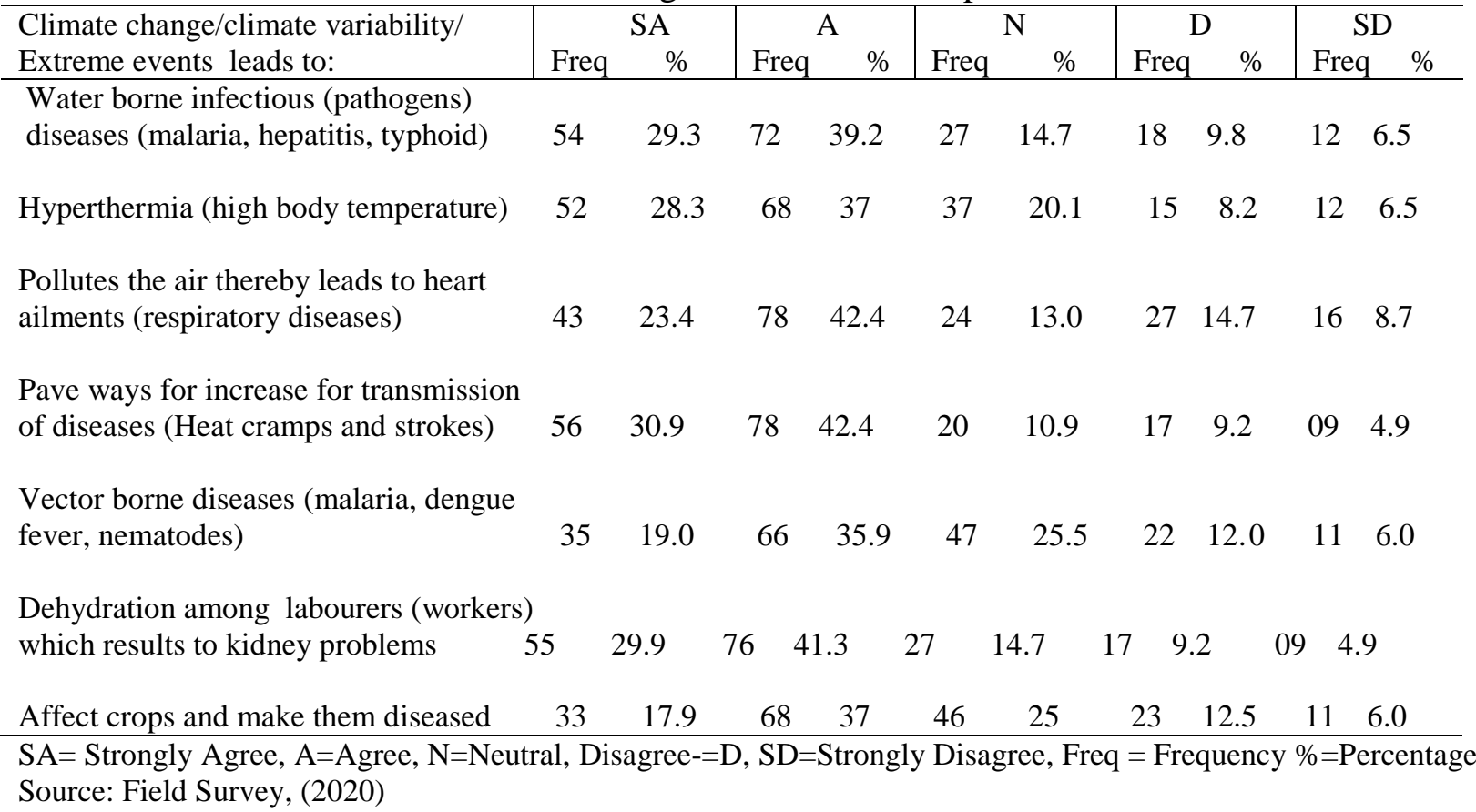

Further investigation on the health effects of climate change reveals that $19 \%$ are strongly of the view that it leads to vector borne diseases such as malaria, dengue fever and nematode infections among others, 35.9\% agreed, neutral (no response) recorded $25.5 \%$ and $12 \%$ disagreed while $6 \%$ strongly disagreed. This reveals that climate change can result to vector borne infectious diseases (Amadi and Udo, 2015). On the aspect of the view that climate change leads to dehydration of people especially workers (labourers) exposed to the extreme events and results to kidney diseases received a response of $29.9 \%$ of strongly agreed. The highest response of $41.3 \%$ agreed, 14.7 showed no response, $9.2 \%$ disagreed and the least respondents of $4.9 \%$ strongly disagreed with the view. The study therefore indicates that dehydration can occur as a result of climate change as also opined byFederal Ministry of Environment, (2014). Further quest on the health effects of climate change shows that $17.9 \%$ strongly agreed that climate change affects crops and make them diseased. The highest respondents of $37 \%$ agreed, neutral recorded $25 \%$ and $12.5 \%$ 
disagreed while only $6 \%$ strongly agreed with the view. This reveals that climate change makes crops to be diseased and when consumed by man or animals there is the tendency of being ill as also reported by Orisa-ubi (2020).

In similar vein, the health effects of climate change can be likened to the work of Patz et al. (2000) who put them as shown on Figure 2 where different courses or tract were identified along with the modulating influences.

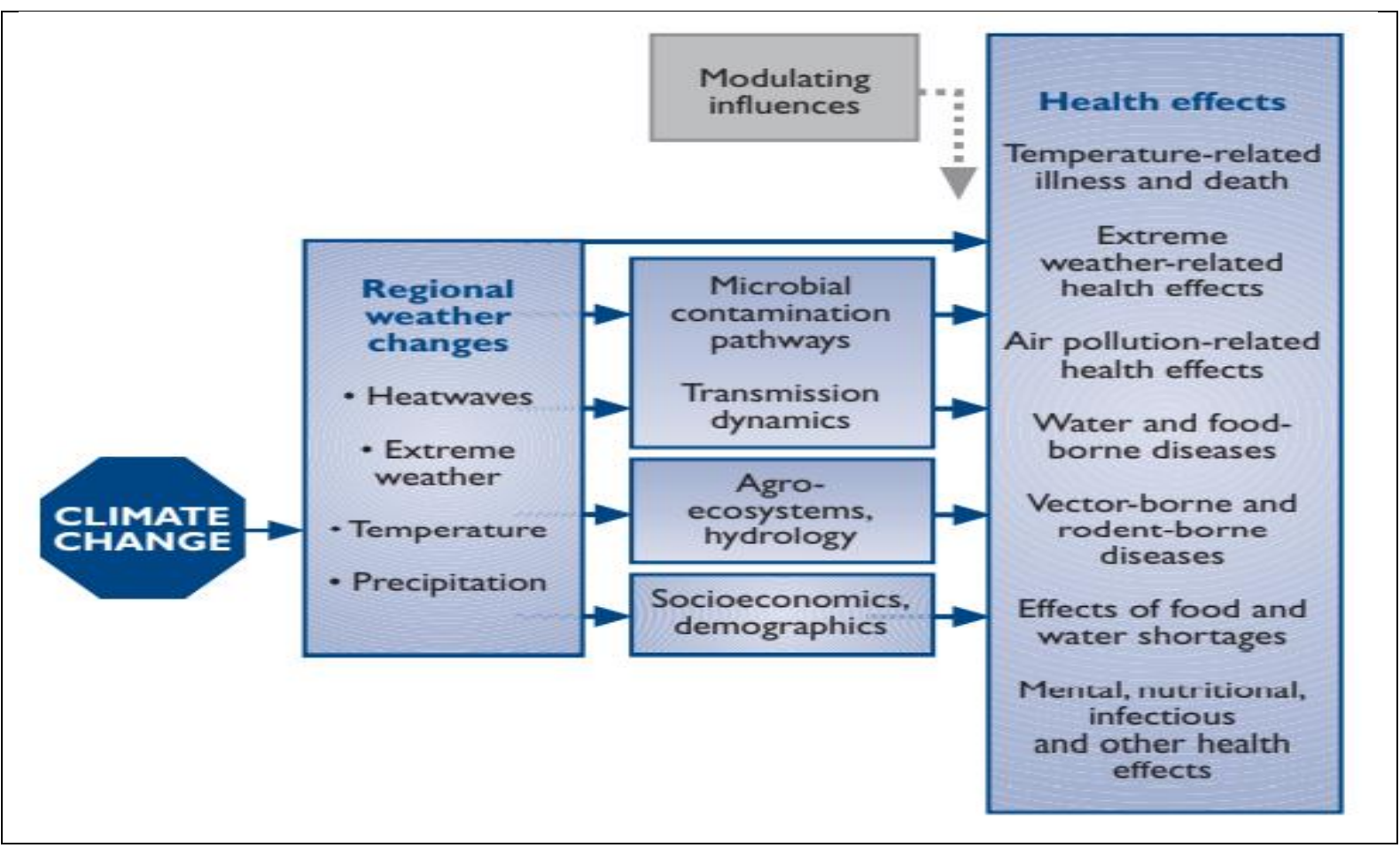

Figure 2: Tracts of the health effects of climate change Source: Adapted from Patz et al. (2000)

It is interesting to note that none of the responses on the various environmental and health effects of climate change views recorded $50 \%$ and above except the view on climate change effects on agricultural productions where $51.6 \%$ respondents agreed with the view. In most cases it takes both cumulative of the percentages of strongly agree and agree to match 50\% and in most perceptions above $70 \%$. More still, the percentages of those that reported neutral was quite alarming and this reveals that despite the purposeful sampling employed the knowledge of climate change in the metropolis is inadequate and call for intensive enlightenment. However, based on the results obtained it can be deduced that climate change has significant negative effects on the environment and health of living things.

\section{CONCLUSION AND RECOMMENDATION}

The study investigated the environmental and health effects of climate change in Kaduna metropolis with a view to educate the residents on the dangers associated with the environmental changes as a result of the natural and anthropogenic activities. The results obtained revealed that 
climate change contributes to environmental effects such as extreme events (rise in temperature, lightning and thunderstorm, landslides, floods, droughts, bush fires), rise in sea level, flooding, desert encroachment, drought, land degradation, run-off, soil erosion and food scarcity. It also leads to health effects such as increase of heat which leads dehydration and spread of diseases such as; hyperthermia, skin cancer, cholera, malaria, heart ailments, diseased crops among others. Averagely the responses of those who strongly agreed and agreed to the environmental and health effects of climate change under the various views were above $50 \%$. The study also discovered that many people in the metropolis are still no conversant with climate change and its effects on the community.

It is on the basis of the findings on the environmental and health effects of climate change that the study recommends the following:

a. There should be intensive and elaborate public enlightenment and education on the general concepts of climate change and the effects it has on people and the environment.

b. Environmental impact assessments should be thoroughly carried when embarking on developmental projects in the metropolis.

c. Factories, vehicle users and households should be compelled to comply with existing policies and laws regulating the emission of greenhouse gases.

d. Violators of environmental laws should be heavily sanctioned.

e. The residents should be educated on the mitigation measures such as the required dress code for each session and tree planting among others. 


\section{REFERENCE}

Abaje, I.B., Sawa, B.A., Iguisi, E.O. and Ibrahim, A.A. (2015). A Quantitative approach to vulnerability assessment of rural communities to climate change in Kaduna State, Nigeria. Nigerian Geographical Journal, New Series, 10 (2), 180-195.

Akande, A., Costa, A. C., Meteu, J. and Henriques, R. (2017). Geospatial Analysis of Extreme Weather Events in Nigeria (1985- 2015) Using Self-Organizing Maps. Advances in Meteorology. https://doi.org/10.1155/2017/8576150

Akeh, G.I. and Mshelia, A.D. (2016). Climate change and urban flooding: Implications for Nigeria's built environment. https://www.preventionweb.net/publications/view/50865

Akpodiogaga, P and Odjugo, O. (2010). General overview of climate change impacts in Nigeria, Journal of Human Ecology, 29(1): 47-55.

Al-Amin, M. A. and Dadan-Garba, A. (2014). Urban Vegetation Study of Kaduna Metropoli using GIS and remotely sensed Data. Journal of Natural Sciences Research www.iiste.org Vol.4 (2): 160-171.

Amadi, S.O. and Udo, S.O. (2015). Climate change in contemporary Nigeria: An empirical analysis of trends, impacts, challenges and coping strategies. IOSR Journal of Applied Physics, 7(2): 1-9. http://www.iosrjournals.org

Amanchukwu, R. N. et al. (2015). Climate change education in Nigeria: The role of curriculum review. Education, 5(3): 71-79. https://www.researchgate.net

Audrey, A. (2019). Tackling the Water Crisis-Leaving No One Behind; A text delivered by The Director General of UNESCO on World Water Day, 22nd March, 2019 www.worldwaterday.org

BBC World Service Trust (2008). Talk Climate; The Public Understanding of Climate Research, www.africatalksclimate.com

Benedine, A. and Adamu, I. T. (2017). Determining the Rate and Pattern of the Spatio-Temporal Growth of Kaduna Metropolis, Kaduna. InternationalJournal of Geography, Environment and Earth Science. Vol. 11(1): 1 - 10

Buba, (2004). Climate change and water problems in Chad Republic, Journal of Arid Environment. 3(2): 42-50.

Butu and Mshelia, (2017). Assessment of the Effectiveness of Municipal Solid Waste Management in Tarauni Local Government Area, Kano State, Nigeria. Development Journal of Science and Technology Research. Vol. 6 (2): 141 - 154. 
De Chavez, R and Tauli-Corpuz,V. (2008). Guide to climate change and indigenous peoples. Retrieved on 26th June, 2009 from www.tebtebba.org

Ebele, N. E. and Emodi, N. V. (2016). Climate change and its impact in Nigerian economy. Journal of Scientific Research \& Reports, 10(6), 1-13. http://www.journaljsrr.com/index.php/JSRR/article/view/21917/40737

Elisha, I., Sawa, B. A. and Lawrence, E. U. (2017). Evidence of climate change and adaptation strategies among grain farmers in Sokoto State, Nigeria. IOSR Journal of Environmental Science, Toxicology and Food Technology, 11(3): 1-7.

Federal Ministry of Environment (2014). United Nations Climate Change Nigeria. National $\begin{array}{lllll}\text { Communication } & \text { (NC). } & \text { NC } & 2 . & 2014 .\end{array}$ https://unfccc.int/sites/default/files/resource/nganc2.pdf

Fingesi, E.T, (2001) The Effect of Sectarian Riots on Housing Supply in Barnawa, Unpublished MSc Thesis, Department of Geography, FASS, Nigerian Defence Academy, Kaduna.

Hippocrates, (1978). Airs, waters and places. An essay on the influence of climate, water supply and situation on health. In: Hippocratic Writings. Lloyd G.E.R. ed. London, UK, Penguin,

Houghtoon, J. (2011). Global warming, climate change and sustainability: Challenges to scientist, Policy makers and Christians. Briefing paper 14, fourth Edition

IPCC (2007). Climate change 2007. The fourth assessment report (AR4). Synthesis report for policy makers http://www.ipcc.ch/pdf/assessmentreport/ar4/syr/ar4-syr-spm.pdf. Accessed 10th August, 2009

Jeffe, D. (2007). Effects of Climate Change. New York: Cambridge university press.

Mande, K. H. (2020). Assessing the Impact of Climate Change on the Built Environment in Kaduna Metropolis and Environs, Science World Journal, 15(3):78-84 https://doi.org/10.47514/swj/15.03.2020.011

Mshelia, S. S., Mbaya, Y.A..and Emmanuel, G. (2020). Environmental Effects of Cutting Down of Urban Trees for Road Constructions in Kaduna Metropolis. International Journal of Advances in Engineering and Management. Volume 2 (1): 176-186. www.ijaem.net

Nenibarini, Z. (2007). Climate change and flooding: fate of riverine communities in the Niger Delta. Conservation Programme Centre for Environment, Human Rights and Development (CEHRD), Eleme.

Odjugo, P. A. O. (2010). General Overview of Climate Change Impacts in Nigeria. Journal of Human Ecology, 29(1): 47-55 
Ogunkalu1, O. A., Sodimu, A. I., Sulaiman, R. A. and Adedire, O. O. (2017).Survey of Benefits and Constraints of Urban Trees in Kaduna Metropolis World News of Natural Sciences 11 (2017) 19-27 worldnewsnaturalsciences.com

Olapido, E. (2010). Towards enhancing the adaptive capacity of Nigeria: a review of the country's state of preparedness for climate change adaptation. Heinrich Böll Foundation Nigeria. https://ng.boell.org/sites/default/files/uploads/2013/10/nigeria

Olaniyi, O. A., Ojekunle, Z. O. and Amujo, B. T. (2013). Review of climate change and its effect on Nigeria ecosystem. International Journal of African and Asian Studies, 1(1):57-65. https://pdfs.semanticscholar.org

Orisa-Ubi, C. O. (2020). Health and environmental problems associated with climate change in Rivers State. International Journal of Geography and Environmental Management 6(3): 24-36.

Patz, J. A., McGeehin, M. A., Bernard, S. M., Ebi, K. L., Epstein, P. R., Grambsch, A., Gubler, D. J., Peither, P., Romieu, I., Rose, J. B., Samet, J. M. and Trtanj, J. (2000). The potential health impacts of climate variability and change for the United States: executive summary of the report of the health sector of the US National Assessment. Environmental Health Perspectives, 108: 367-376

Sayne, A. (2011). Climate change adaptation and conflict in Nigeria. Washington, DC: USIP. https://www.usip.org/sites/default/files/Climate_Change_Nigeria.pdf

United Nations Framework Convention on Climate Change- UNFCCC (1992). Retrieved from (www.http://unfccc.int/2860.php).

Vitousek, P.M. et al. Human domination of Earth's ecosystems. Science 277: 494-499 (1997).

World Health Organisation (2004). In de Chavez and Tauli-Corpuz. (eds.) (2008). Guide to climate change. Retrieved on 26th June, 2009 from www.tebtebba.org 